\title{
Palmitate-induced skeletal muscle insulin resistance does not require $\mathrm{NF}-\boldsymbol{\kappa} \mathrm{B}$ activation
}

\author{
Pascal P. H. Hommelberg • Jogchum Plat • Lauren M. Sparks • \\ Annemie M. W. J. Schols • Anon L. M. van Essen • Marco C. J. M. Kelders • \\ Denis van Beurden · Ronald P. Mensink - Ramon C. J. Langen
}

Received: 8 April 2010/Revised: 16 July 2010/ Accepted: 17 August 2010/Published online: 5 September 2010

(C) The Author(s) 2010. This article is published with open access at Springerlink.com

\begin{abstract}
Palmitate activates the NF- $\kappa \mathrm{B}$ pathway, and induces accumulation of lipid metabolites and insulin resistance in skeletal muscle cells. Little information is available whether and how these processes are causally related. Therefore, the objectives were to investigate whether intra-cellular lipid metabolites are involved in FA-induced NF- $\kappa$ B activation and/or insulin resistance in skeletal muscle and to investigate whether FA-induced insulin resistance and NF- $\kappa$ B activation are causally related. Inhibiting DGAT or CPT-1 by using, respectively, amidepsine or etomoxir increased DAG accumulation and sensitized myotubes to palmitate-induced insulin resistance. While co-incubation of palmitate with etomoxir increased NF- $\kappa \mathrm{B}$ transactivation, co-incubation with amidepsine did not, indicating that DAG accumulation is associated with insulin resistance but not with $\mathrm{NF}-\kappa \mathrm{B}$ activation.
\end{abstract}

Electronic supplementary material The online version of this article (doi:10.1007/s00018-010-0515-3) contains supplementary material, which is available to authorized users.

P. P. H. Hommelberg · J. Plat · L. M. Sparks ·

D. van Beurden - R. P. Mensink

Department of Human Biology,

Nutrim School for Nutrition,

Toxicology and Metabolism,

Maastricht University Medical Centre,

Maastricht, The Netherlands

\begin{abstract}
A. M. W. J. Schols - A. L. M. van Essen ·
M. C. J. M. Kelders - R. C. J. Langen $(\bowtie)$

Department of Respiratory Medicine, Nutrim School

for Nutrition, Toxicology and Metabolism,

Maastricht University Medical Centre,

P.O. Box 616, 6200 MD Maastricht, The Netherlands

e-mail: r.langen@pul.unimaas.nl
\end{abstract}

P. P. H. Hommelberg - R. P. Mensink

Top Institute Food and Nutrition, Wageningen, The Netherlands
Furthermore, pharmacological or genetic inhibition of the NF- $\kappa$ B pathway could not prevent palmitate-induced insulin resistance. In conclusion, we have demonstrated that activation of the NF- $\kappa \mathrm{B}$ pathway is not required for palmitateinduced insulin resistance in skeletal muscle cells.

Keywords Skeletal muscle - Insulin resistance . Palmitate $\cdot$ Nuclear factor-kappa B · Glucose uptake

\section{Introduction}

Insulin resistance is recognized as an important risk factor in the development of type 2 diabetes, the prevalence of which is rapidly increasing [1]. Although it is generally accepted that this may relate to a Western-type diet high in saturated fatty acids [2], the detailed pathogenesis underlying the initiation of insulin resistance is still poorly understood. Since skeletal muscle is responsible for $70-80 \%$ of insulin-stimulated glucose uptake, skeletal muscle insulin resistance is most likely a major determinant of type 2 diabetes [3].

Type 2 diabetic patients are characterized by an elevation in plasma free fatty acids (FFA) [4]. These FFA play a major role in the pathogenesis of insulin resistance, since lowering FFA levels in the plasma significantly improves insulin sensitivity $[5,6]$, whereas lipid infusion leading to increased plasma FFA induces skeletal muscle insulin resistance in rodents and humans [7-9]. It is thought that circulating FFA interfere with insulin signaling as a consequence of cellular FA oversupply or impaired mitochondrial FA oxidation, leading to intra-muscular accumulation of FA metabolites. Increased levels of the lipid metabolite diacylglycerol (DAG) in skeletal muscle indeed accompanies diet-induced insulin resistance in 
rodents [10] and lipid infusion-induced insulin resistance in humans [8]. Whether DAG is the crucial trigger and via which cellular processes DAG accumulation leads to insulin resistance is still unclear. However, since DAG accumulation during lipid infusion coincides with nuclear factor kappa B $(\mathrm{NF}-\kappa \mathrm{B})$ activation in insulin-resistant muscle, NF- $\kappa \mathrm{B}$ has been implicated in the mechanism underlying FA-induced DAG-mediated muscular insulin resistance [8]. Although several in vitro studies in skeletal muscle provide evidence that long-chain saturated FAinduced insulin resistance coincides with DAG accumulation [11] and activation of the $\mathrm{NF}-\kappa \mathrm{B}$ pathway [12-14], little information is available if and how these processes are causally related. Therefore, the first objective of this study was to investigate whether DAG accumulation is involved in NF- $\kappa \mathrm{B}$ activation and/or FA-induced insulin resistance in skeletal muscle by interfering with $\beta$-oxidation and DAG to TAG conversion.

Several studies in rodents and humans showed that insulin resistance induced by hyperlipidemia (lipid infusion) or an obesity-inducing high fat diet was associated with decreased $\mathrm{I} \kappa \mathrm{B} \alpha$ protein levels in skeletal muscle, which is suggestive for $\mathrm{NF}-\kappa \mathrm{B}$ activation [8, 15, 16]. Furthermore, whole body inhibition of NF- $\kappa \mathrm{B}$ activity by pharmacological means or by heterozygous deletion of the NF- $\kappa \mathrm{B}$-activating kinase IKK-2, prevented lipid infusion-, obesity- and diet-induced insulin resistance [17, 18], illustrating an important role for $\mathrm{NF}-\kappa \mathrm{B}$ in whole body glucose homeostasis.

However, the specific contribution of NF- $\kappa \mathrm{B}$ activation in skeletal muscle was not assessed in these studies. Mice with a muscle-specific inhibition of NF- $\kappa \mathrm{B}$ by transgenic expression of the $\mathrm{I} \kappa \mathrm{B} \alpha$ super-repressor (MISR mice) were not protected against the development of diet-induced whole body insulin resistance [19], and muscle-specific IKK-2 deficient mice showed no differences in whole body glucose homeostasis after gold thioglucose-induced obesity [20]. Since insulin resistance of other tissues could potentially mask a protective effect of $\mathrm{NF}-\kappa \mathrm{B}$ inhibition on muscle glucose homeostasis, in this respect, studies using cultured muscle cells are of great advantage. In L6 myotubes, it has been shown that palmitate-induced insulin resistance could be prevented by pharmacological inhibitors of IKK and NF- $\kappa \mathrm{B}$ nuclear translocation in L6 myotubes [21, 22]. In contrast, non-saturated FA-induced $\mathrm{NF}-\kappa \mathrm{B}$ activation in absence of insulin resistance has been described in skeletal muscle [23]. Moreover, several studies showed that stimulation of muscle cells with TNF- $\alpha$, a well-known and potent $\mathrm{NF}-\kappa \mathrm{B}$ activator, does not induce insulin resistance [24-26], while others showed that muscle-specific transgenic expression of activated IKK in mice (MIKK mice) [19] and over-expression of IKK-2 and p65 via in vivo electrotransfer in rat muscles does not induce insulin resistance [27]. From the latter studies, it appears that muscular $\mathrm{NF}-\kappa \mathrm{B}$ activation per se is not sufficient to induce insulin resistance.

Considering that these conflicting results regarding the requirement of muscular $\mathrm{NF}-\kappa \mathrm{B}$ activation in FA-induced insulin resistance may be attributable to differences in strategies to modulate $\mathrm{NF}-\kappa \mathrm{B}$ activity, the second objective of this study was to address the contribution of NF- $\kappa \mathrm{B}$ activation to palmitate-induced insulin resistance in cultured skeletal muscle using both pharmacological and genetic approaches to inhibit NF- $\kappa \mathrm{B}$ activity.

\section{Materials and methods}

\section{Cell culture}

The C2C12 murine skeletal muscle cell line (ATCC CRL1772. Manassas, VA), stably transfected with the $6 \kappa \mathrm{B}$ TK-luciferase, was used for the assessment of $\mathrm{NF} \kappa \mathrm{B}$ transcriptional activity. In brief, $\mathrm{C} 2 \mathrm{C} 12$ cells were plated $\left(1 \times 10^{4}\right.$ cells $\left./ \mathrm{cm}^{2}\right)$ on growth factor reduced Matrigel (Becton-Dickinson Labware, Bedford, MA, USA) coated (1:50 in Dulbecco's modified Eagle's medium, DMEM) dishes, as described previously [28]. C2C12 myoblasts were cultured in growth medium (GM), composed of low glucose DMEM containing antibiotics $(50 \mathrm{U} / \mathrm{ml}$ penicillin and $50 \mu \mathrm{g} / \mathrm{ml}$ streptomycin; both from Gibco-Invitrogen, Rockville, MD, USA) and 9\% (vol/vol) fetal bovine serum (FBS; PAA Laboratories, UK). To induce differentiation, GM was replaced by differentiation medium (DM), containing DMEM with $1 \%$ (vol/vol) heat-inactivated FBS and antibiotics. As a positive control for $\mathrm{NF}-\kappa \mathrm{B}$ transcriptional activity, murine TNF $\alpha$ (Calbiochem, San Diego, CA, USA) was added to the dishes.

Myoblasts from the L6 rat skeletal muscle cell line were cultured in GM, composed of $\alpha$-MEM (Gibco-Invitrogen) containing $9 \%$ (vol/vol) FBS and antibiotics. The plating density used for the experiments was $2 \times 10^{4} / \mathrm{cm}^{2}$. After $24 \mathrm{~h}$ of culturing in growth medium, differentiation was induced by replacing GM with DM, containing $\alpha$-MEM with $2 \%$ (vol/vol) heat-inactivated FBS and antibiotics.

Amidepsine A (Alexis, San Diego, CA, USA), etomoxir and parthenolide (both from Sigma, St. Louis, MO, USA) were added $30 \mathrm{~min}$ before palmitate incubations.

All experiments described for both cell lines were performed in 5- or 6-day differentiated myotubes unless stated otherwise.

Palmitate incubations

Palmitate (C16:0; Sigma) stock solutions of $40 \mathrm{mmol} / \mathrm{l}$ were prepared in ethanol. Before application to the cells, 
palmitate was conjugated to bovine serum albumin (BSA) by diluting the palmitate solution with differentiation medium containing $1 \%(\mathrm{w} / \mathrm{v})$ palmitate-free BSA (Sigma). Solutions were filter-sterilized before addition to the cells. Because of different sensitivities of both cell lines towards FA-induced NF- $\kappa \mathrm{B}$ activation and insulin resistance [12], maximal palmitate concentrations used are $200 \mu \mathrm{mol} / \mathrm{l}$ for L6 myotubes and $400 \mu \mathrm{mol} / 1$ for $\mathrm{C} 2 \mathrm{C} 12$ myotubes.

Vehicle controls contained equal amounts of ethanol $(\max 1 \%$ in $\mathrm{C} 2 \mathrm{C} 12$ or $0.5 \%$ in L6) (v/v) and BSA (1\% (w/v)).

\section{Diacylglycerol analysis}

Freeze-dried L6 myotubes were extracted overnight at $4^{\circ} \mathrm{C}$ with chloroform-methanol ( $2: 1$ by volume), containing $10 \mathrm{mg} / \mathrm{l}$ of butylated hydroxytoluene. After centrifugation, the supernatant was evaporated under nitrogen gas. Lipids were reconstituted in chloroform-methanol (1:1), containing $10 \mathrm{mg} / \mathrm{l}$ of butylated hydroxytoluene, spotted onto TLC plates and developed in a solvent containing petroleumbenzin-diethyl ether-acetic acid (120:25:1,5 by volume). The DAG fractions were identified against a DAG standard (Sigma) and scraped into a vial. From the DAG extracts, methyl esters were prepared by transmethylation using a mixture of toluene-methanol-(BF3-methanol 14\%) $\left(20-55-25 \%\right.$ by volume) at $100^{\circ} \mathrm{C}$ for $30 \mathrm{~min}$. The fatty acid methyl esters were separated by capillary gas liquid chromatography using a $50 \mathrm{~m} \times 0.25 \mathrm{~mm}$ CP-sil 88 silica column (Varian) with helium as carrier gas at a flow of $130 \mathrm{kPa}$. Fatty acids were identified by comparison with a standard mixture of fatty acid methyl esters.

Alternatively, cells were pre-incubated for $16 \mathrm{~h}$ with $\left[1-{ }^{14} \mathrm{C}\right]$ palmitate $(0.5 \mu \mathrm{Ci} / \mathrm{ml}$; PerkinElmer, Boston, MA, USA) and respective non-labeled (cold) palmitate $(100 \mu \mathrm{M})$. Following incubation, cells were washed twice with $1 \times$ PBS and harvested into $0.25 \mathrm{ml}$ of $0.05 \%$ SDS for subsequent protein measurement and total lipid extraction with $1 \mathrm{ml}$ of chloroform/methanol $(2 \mathrm{v} / 1 \mathrm{v})$. Lipids were washed with $70 \%$ ethanol and re-dissolved for thin layer chromatography (TLC) (Anal Tech TLC plates; Whatman, Kent, ME, USA) and run in a mobile phase containing hexane/diethyl ether/acetic acid, v/v/v, 80:20:1). Bands corresponding diacylglycerol (DAG) were scraped and transferred into scintillation vials, and radioactivity was measured on a multipurpose scintillation counter (LS 6500; Beckman Coulter, Brea, CA, USA). All assays were performed in triplicate, and data were normalized to protein content.

Transfections and plasmids

Stable cell lines were created by transfection with Nanofectin (PAA) according to manufacturers' recommendations.
To inhibit NF- $\kappa \mathrm{B}$ activation, L6 myoblasts $\left(3 \times 10^{3}\right.$ cells $/ \mathrm{cm}^{2}$ ) were stably transfected with nanofectin in the presence of a plasmid encoding $\mathrm{I} \kappa \mathrm{B} \alpha-\mathrm{SR}(3 \mu \mathrm{g})$, which was constitutively expressed under control of the SFFV-LTR (pSFFV-NEO I $\kappa \mathrm{B} \alpha-\mathrm{SR}$ ), kindly provided by Dr. Rosa Ten (Mayo Clinic, Rochester, MN, USA). A control cell line was created using the same strategy, with plasmid DNA containing the neomycin resistance gene (pSV2-Neo; Stratagene, La Jolla, CA, USA). For selection of positive clones, cells were cultured in GM containing the presence of $800 \mu \mathrm{g} / \mathrm{ml} \mathrm{G}-418$ (Calbiochem).

\section{NF- $\kappa \mathrm{B}$ transcriptional activity}

To determine NF- $\kappa \mathrm{B}$ transcriptional activity, luciferase activity was measured in a NF- $\kappa \mathrm{B}$ sensitive reporter cell line as previously described [28]. After the appropriate incubation time with the various stimuli, cells were washed twice with cold phosphate-buffered salin (PBS) and lysed by adding $100 \mu \mathrm{l} 1 \times$ Reporter Lysis Buffer (Promega, Madison, WI, USA). After incubation on ice for $10 \mathrm{~min}$, cell lysates were centrifuged $(13,000 \mathrm{~g}, 2 \mathrm{~min})$ and stored at $-80^{\circ} \mathrm{C}$ until analysis. Luciferase activity was measured according to the manufacturers' instructions (Promega) and corrected for total protein content (Bio-Rad, Hercules, CA, USA).

\section{Electrophoretic mobility shift analysis}

To determine DNA binding activity of NF- $\kappa \mathrm{B}$, complexes binding to an oligonucleotide containing a NF- $\kappa \mathrm{B}$ consensus sequence were analyzed by EMSA. Nuclear extracts were isolated to analyze NF- $\kappa \mathrm{B}$ DNA binding. To this end, cells were harvested following experimental treatments and lysed on ice in $400 \mu \mathrm{l}$ buffer containing $20 \mathrm{mmol} / \mathrm{l} \mathrm{HEPES}$, $\mathrm{pH} 7.8,20 \mathrm{mmol} / \mathrm{l} \mathrm{KCl}, 4 \mathrm{mmol} / \mathrm{l} \mathrm{MgCl}_{2}, 0.2 \mathrm{mmol} / \mathrm{l}$ EDTA, $1 \mathrm{mmol} / \mathrm{l} \mathrm{DTT}, 0.2 \mathrm{mmol} / \mathrm{l}$ sodiumorthovanadate, $0.4 \mathrm{mmol} / \mathrm{l}$ phenylmethyl sulfonylfluoride, $0.3 \mu \mathrm{g} / \mathrm{ml}$ leupeptin and $0.2 \mathrm{mmol} / \mathrm{l} \mathrm{NaF}$ for $15 \mathrm{~min}$. Subsequently, $25 \mu \mathrm{l}$ $10 \%$ Nonidet P40 was added and samples were vortexed for $15 \mathrm{~s}$ followed by centrifugation $(14,000 \mathrm{~g}$ for $30 \mathrm{~s})$. Supernatants were removed and pelleted nuclei were washed with the previously mentioned buffers and resuspended with a buffer containing $100 \mathrm{mmol} / \mathrm{l}$ HEPES, $\mathrm{pH}$ 7.8, $100 \mathrm{mmol} / \mathrm{l} \mathrm{KCl}, \quad 600 \mathrm{mmol} / \mathrm{l} \mathrm{NaCl}, \quad 0.2 \mathrm{mmol} / \mathrm{l}$ EDTA, $20 \%$ glycerol, $1 \mathrm{mmol} / \mathrm{l}$ DTT, $0.2 \mathrm{mmol} / \mathrm{l}$ sodiumorthovanadate, $0.667 \mathrm{mmol} / 1$ phenylmethyl sulfonylfluoride and $0.2 \mathrm{mmol} / \mathrm{l} \mathrm{NaF}$. Nuclei were mixed vigorously for $20 \mathrm{~min}$ at $4{ }^{\circ} \mathrm{C}$ using a rotating platform, centrifuged $(14,000 \mathrm{~g}$ for $5 \mathrm{~min})$ and samples were stored at $-20^{\circ} \mathrm{C}$ (for protein concentration determination) and $-80^{\circ} \mathrm{C}$ (for DNA binding activity measurements). $7 \mu \mathrm{g}$ nuclear cell extracts were used per binding reaction, and 
protein-DNA complexes were resolved on a $5 \%$ polyacrylamide gel in $0.25 \times$ Tris borate-EDTA buffer at $160 \mathrm{~V}$ for $2 \mathrm{~h}$. Gels were dried and exposed to film (X-Omat Blue XB-1; Kodak, Rochester, NY, USA). Shifted complexes were quantified by phosphoimager analysis (Bio-Rad). To determine the presence of RelA (p65) by supershift analysis, nuclear extracts were pre-incubated with an antibody specific to the RelA subunit of NF- $\kappa \mathrm{B}$ (Santa Cruz Biotechnology).

\section{$\left[{ }^{3} \mathrm{H}\right]$ deoxyglucose uptake}

Basal and insulin-dependent deoxyglucose uptake was determined as described previously [12]. In brief, L6 myotubes with or without FA preincubation were serum deprived for $3 \mathrm{~h}$ prior to incubation with $25 \mathrm{nmol} / \mathrm{l}$ insulin (Sigma) for $15 \mathrm{~min}$ at $37^{\circ} \mathrm{C}$ in glucose-free medium. Label

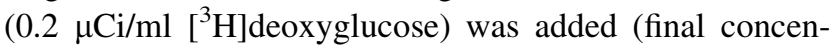
tration of $20 \mu \mathrm{mol} / \mathrm{l}$ ) and incubated for $20 \mathrm{~min}$ at $37^{\circ} \mathrm{C}$. Glucose transport was terminated by washing three times with an ice-cold stop-solution containing $0.2 \mathrm{mmol} / \mathrm{l}$ phloretin and cells were harvested in $0.5 \mathrm{ml} 0.05 \mathrm{~mol} / \mathrm{l}$ $\mathrm{NaOH}$. Cell-associated radioactivity was determined by scintillation counting.
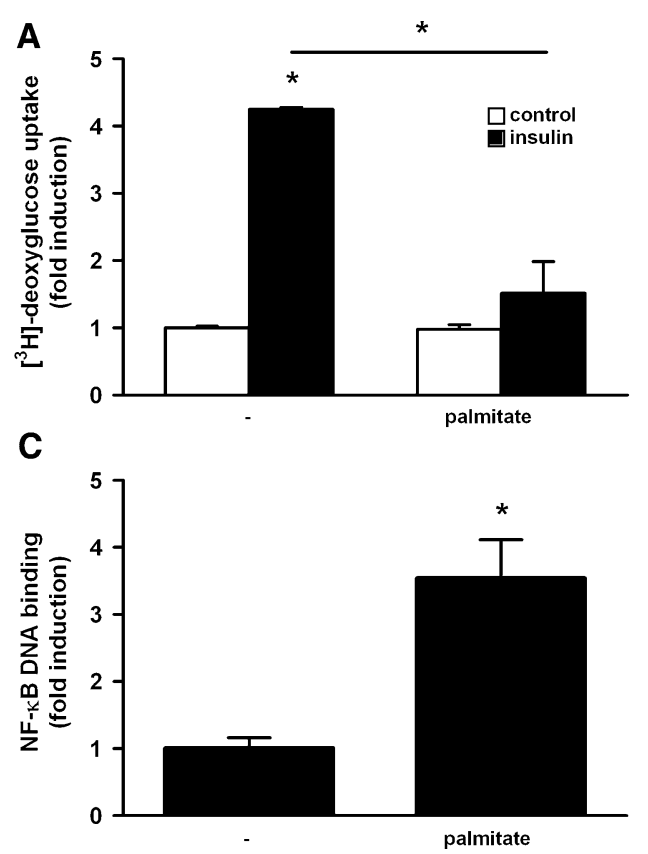

Fig. 1 Palmitate induces insulin resistance, DAG accumulation and NF- $\kappa \mathrm{B}$ transactivation in myotubes. a L6 myoblasts were differentiated for 5 days and subsequently incubated for $16 \mathrm{~h}$ with and without $200 \mu \mathrm{mol} / 1$ palmitate prior to stimulation with $25 \mathrm{nmol} / \mathrm{l}$ insulin for $15 \mathrm{~min}$ (white bars no insulin stimulation; black bars insulin stimulation). 2-deoxyglucose uptake was measured as described in "Materials and methods", and insulin-stimulated glucose uptake was expressed as fold induction over basal (non-insulin stimulated) glucose uptake. $* P<0.05$. Alternatively, L6 myotubes were incubated with $200 \mu \mathrm{mol} / \mathrm{l}$ palmitate for $16 \mathrm{~h}$, after which
Statistical analysis

SPSS (version 16.0) was used for statistical analysis. Data were analyzed by one-way ANOVA, and the various treatment groups were compared by using the post-hoc Bonferroni test in which a $P<0.05$ was considered statistically significant. Data is presented as means \pm SD. Data shown are representative examples of three independent experiments.

\section{Results}

Palmitate induces insulin resistance, DAG accumulation and NF- $\kappa \mathrm{B}$ activation in myotubes

Verifying previous findings considering palmitate-induced insulin resistance, L6 myotubes were treated for $16 \mathrm{~h}$ with $200 \mu \mathrm{mol} / 1$ palmitate. As expected, incubation with palmitate suppressed insulin-stimulated deoxyglucose uptake compared with untreated cells (Fig. 1a). This palmitateinduced insulin resistance coincided with a fivefold increase in diacylglycerol (DAG) accumulation (Fig. 1b). To determine the effects of palmitate incubation on NF- $\kappa \mathrm{B}$
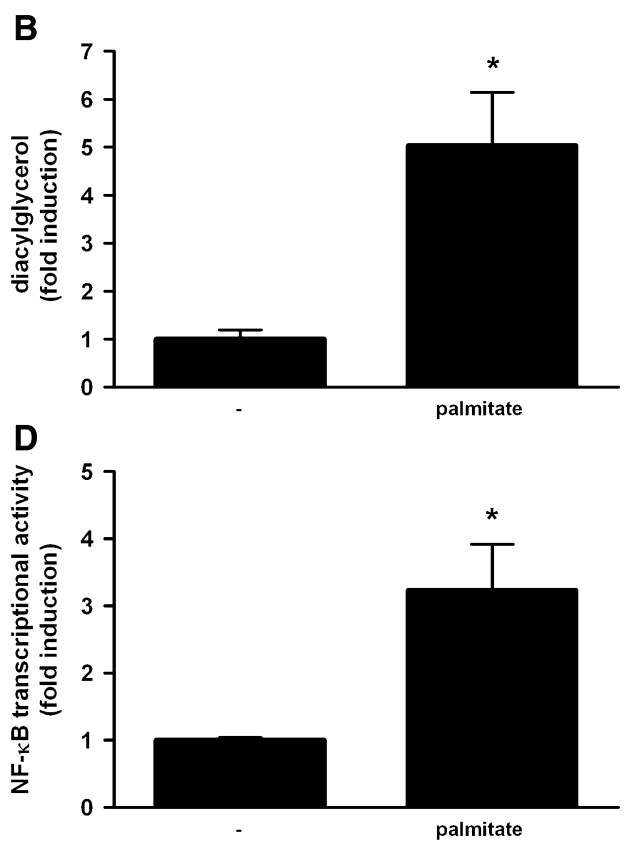

b DAG accumulation was determined by thin layer chromatography, corrected for protein content and expressed as fold change to control, or $\mathbf{c} \mathrm{NF}-\kappa \mathrm{B}$ DNA binding was determined by EMSA, as described in "Materials and methods" and expressed as fold induction over control. ${ }^{*} P<0.05$. d Alternatively, C2C12 myoblasts stably transfected with the $6 \kappa \mathrm{B}$-TK-luciferase construct were differentiated for 5 days and incubated with $400 \mu \mathrm{mol} / \mathrm{l}$ of palmitate for $24 \mathrm{~h}$. Lysates were prepared for assessment of luciferase activity. Values were corrected for protein content and expressed as fold-induction over control. $* P<0.05$ 
activation, NF- $\kappa \mathrm{B}$ DNA binding was investigated in L6 myotubes. Palmitate treatment resulted in a $\sim 3$.2-fold increase in DNA binding (Fig. 1c). To test whether the increased DNA binding led to an increased NF- $\kappa$ B transactivation, we measured transcriptional activity in $\mathrm{C} 2 \mathrm{C} 12$ myotubes, stably transfected with a NF- $\kappa \mathrm{B}$ sensitive reporter construct. Palmitate increased NF- $\kappa \mathrm{B}$ dependent luciferase activity (Fig. 1d), which confirmed the DNA binding results in L6 myotubes.

Blocking $\beta$-oxidation sensitizes myotubes to palmitate-induced insulin resistance and $\mathrm{NF}-\kappa \mathrm{B}$ transactivation

Impaired FA oxidation causes lipid accumulation in skeletal muscle [29]. To assess the effects of intramyocellular lipid (IMCL) accumulation on insulin sensitivity and NF- $\kappa \mathrm{B}$ activity, FA-oxidation was inhibited by blocking carnitine palmitoyltransferase-1 (CPT-1), an enzyme mediating the transport of long chain fatty acids across the mitochondrial membrane. Myotubes were incubated with $80 \mu \mathrm{mol} / \mathrm{l}$ etomoxir, an irreversible inhibitor of CPT-1 [30]. Supplementary Fig. 1 demonstrates that this concentration of etomoxir resulted in a $\sim$ twofold increase in DAG accumulation in presence of $100 \mu \mathrm{mol} / \mathrm{l}$ palmitate. Treatment of etomoxir without additional FA had no effects on insulin-induced glucose uptake (Fig. 2a). Also treatment of myotubes with the low concentration of $100 \mu \mathrm{mol} / \mathrm{l}$ palmitate alone had no effects on insulin sensitivity, while increasing the palmitate concentrations resulted as expected in a reduced insulin-induced glucose uptake. In contrast, co-incubation of palmitate and etomoxir already reduced insulin-stimulated glucose uptake at $100 \mu \mathrm{mol} / \mathrm{l}$ palmitate. Moreover, inhibition of $\beta$-oxidation, inducing DAG accumulation, further enhanced the insulin resistance induced by increasing palmitate concentrations.

To investigate if sensitization to palmitate-induced insulin resistance by etomoxir coincided with enhanced $\mathrm{NF}-\kappa \mathrm{B}$ activation, we determined the effect of co-incubation of etomoxir and palmitate on NF- $\kappa \mathrm{B}$ transcriptional activity (Fig. 2b). Again, etomoxir and $100 \mu \mathrm{mol} / \mathrm{l}$ palmitate alone had no effect compared to control, while coincubation with these two agents simultaneously resulted in an increased NF- $\kappa \mathrm{B}$ transcriptional activity. Palmitate increased NF- $\kappa \mathrm{B}$ transcriptional activity in a dose-responsive manner, whereas etomoxir had a synergistic effect, as it further enhanced (an additional 1.4-1.8 fold) palmitateinduced NF- $\kappa$ B activation. These data reveal that inhibition of $\beta$-oxidation sensitizes myotubes to palmitate-induced $\mathrm{NF}-\kappa \mathrm{B}$ activation and insulin resistance, and suggest that $\mathrm{NF}-\kappa \mathrm{B}$ activation and insulin resistance are coupled under conditions of DAG accumulation.
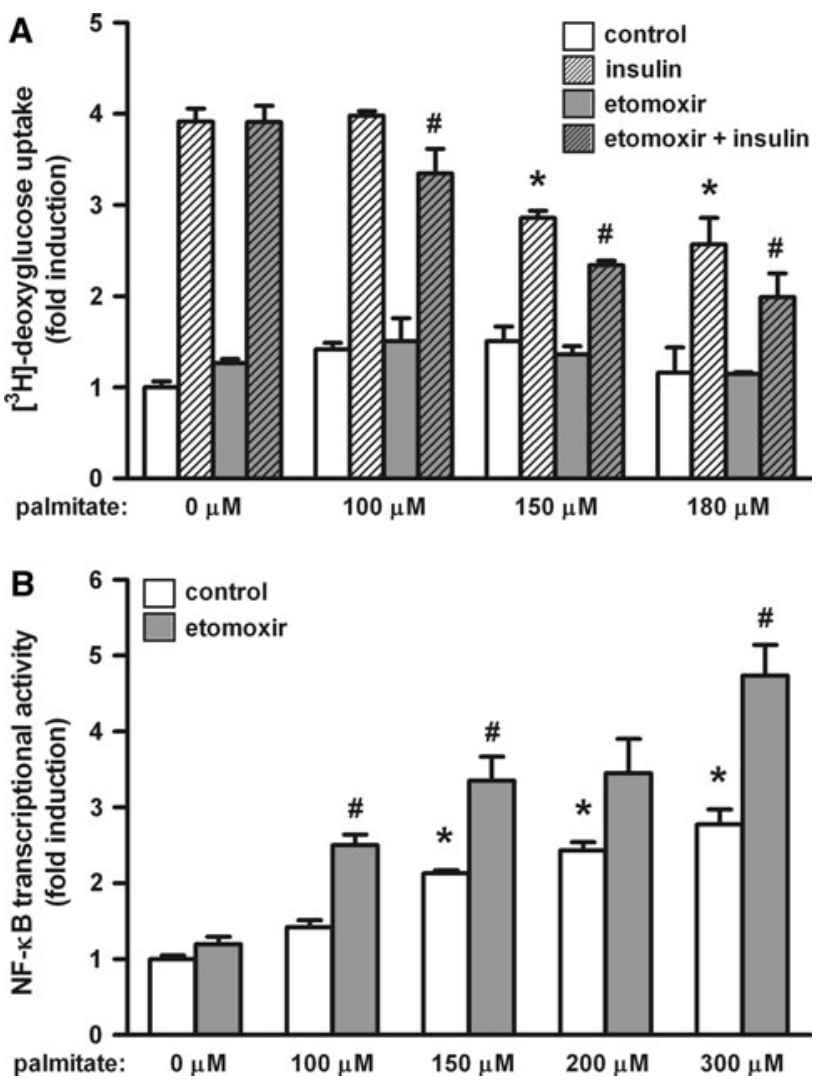

Fig. 2 Blocking $\beta$-oxidation sensitizes myotubes to palmitateinduced insulin resistance and NF- $\kappa \mathrm{B}$ transactivation. a L6 myotubes were treated for $16 \mathrm{~h}$ with the indicated palmitate concentrations in presence (gray bars) or absence (white bars) of etomoxir prior to insulin stimulation (open bars no insulin stimulation; hatched bars insulin stimulation). 2-deoxyglucose uptake was measured as described in "Materials and methods", and insulin-stimulated glucose uptake was expressed as fold induction over basal (non-insulin stimulated) glucose uptake. ${ }^{*} P<0.05$ versus insulin-stimulated cells without palmitate treatment. ${ }^{\#} P<0.05$ versus insulin-stimulated cells with the same palmitate treatment. b $\mathrm{C} 2 \mathrm{C} 12$ myoblasts stably transfected with the $6 \kappa \mathrm{B}-\mathrm{TK}$-luciferase reporter construct were differentiated for 5 days and incubated with indicated palmitate concentrations for $24 \mathrm{~h}$. Cells were co-incubated with (gray bars) and without (white bars) etomoxir. Lysates were prepared for assessment of luciferase activity. Values were corrected for protein content and expressed as fold-induction over control. $* P<0.05$ versus control cells without palmitate treatment. ${ }^{\#} P<0.05$ versus non-etomoxir treated cells with the same palmitate treatment

Segregation of palmitate-induced NF- $\kappa \mathrm{B}$ transactivation and insulin resistance following inhibition of DAG conversion

Diacylglycerol acyltransferase (DGAT) is an enzyme involved in the formation of triglycerides from diacylglycerol (DAG) and acyl-coA in insulin-sensitive tissues like skeletal muscle. In a second approach to study the effects of DAG accumulation on NF- $\kappa \mathrm{B}$ activation and insulin resistance, we used the DGAT inhibitor amidepsine [31]. Amidepsine significantly increased DAG 
accumulation (supplementary Fig. 1) in L6 myotubes. Treatment of myotubes with $10 \mu \mathrm{g} / \mathrm{ml} \quad(\sim 8.8 \mu \mathrm{mol} / \mathrm{l})$ amidepsine in absence of palmitate did not affect insulininduced glucose uptake (Fig. 3a). However, in line with the effects of etomoxir treatment, amidepsine sensitized myotubes to palmitate-induced insulin resistance, and coincubation of $150 \mu \mathrm{mol} / \mathrm{l}$ palmitate with amidepsine already completely abolished insulin-mediated glucose uptake.

In contrast to the effects of etomoxir, amidepsine treatment did not further increase, but even slightly
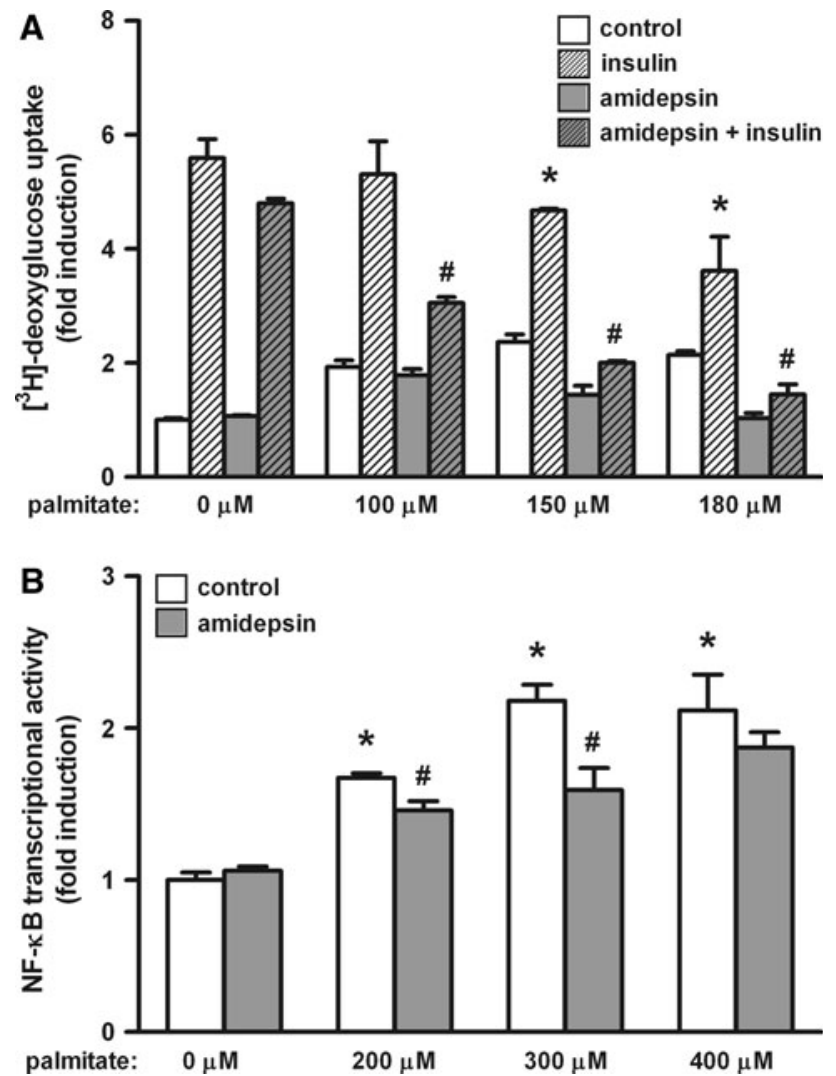

Fig. 3 Segregation of palmitate-induced NF- $\kappa \mathrm{B}$ transactivation and insulin resistance following inhibition of DAG conversion. a L6 myotubes were treated for $16 \mathrm{~h}$ with the indicated palmitate concentrations in presence (gray bars) or absence (white bars) of amidepsine A prior to insulin stimulation (open bars no insulin stimulation; hatched bars insulin stimulation). 2-deoxyglucose uptake was measured as described in "Materials and methods", and insulinstimulated glucose uptake was expressed as fold induction over basal (non-insulin stimulated) glucose uptake. ${ }^{*} P<0.05$ versus insulinstimulated cells without palmitate treatment. ${ }^{\#} P<0.05$ versus insulin-stimulated cells with the same palmitate treatment. b C2C12 myoblasts stably transfected with the $6 \kappa \mathrm{B}$-TK-luciferase reporter construct were differentiated for 5 days and incubated with indicated palmitate concentrations for $24 \mathrm{~h}$. Cells were co-incubated with (gray bars) and without (white bars) amidepsine A. Lysates were prepared for assessment of luciferase activity. Values were corrected for protein content and expressed as fold-induction over control. ${ }^{*} P<0.05$ versus control cells without palmitate treatment. ${ }^{\#} P<0.05$ versus non-amidepsine A treated cells with the same palmitate treatment reduced palmitate-induced NF- $\kappa \mathrm{B}$ transcriptional activity (Fig. 3b), despite a significant increase (38\% compared to palmitate without amidepsine, $P=0.004)$ in $\mathrm{C} 2 \mathrm{C} 12$ myotubes. These findings reveal segregation of palmitateinduced DAG accumulation, insulin resistance and NF- $\kappa$ B activation following inhibition of DAG conversion, and suggest that NF- $\kappa \mathrm{B}$ may not be required for palmitateinduced insulin resistance.

Pharmacological or genetic inhibition of NF- $\kappa \mathrm{B}$ does not prevent palmitate-induced insulin resistance in myotubes

To test whether the NF- $\kappa \mathrm{B}$ pathway is causally linked to palmitate-induced insulin resistance, pharmacological and genetic approaches were employed to inhibit NF- $\kappa$ B. First, $\mathrm{C} 2 \mathrm{C} 12$ myotubes were incubated with $20 \mu \mathrm{mol} / \mathrm{l}$ parthenolide, an agent that inhibits NF- $\kappa \mathrm{B}$ activation by inhibiting IKK activity [32]. The NF- $\kappa \mathrm{B}$ inhibitory capacity of parthenolide was confirmed as it blocked $\mathrm{TNF} \alpha$-induced NF- $\kappa \mathrm{B}$ activity in myotubes (data not shown). Parthenolide resulted in a complete abolishment of palmitate-induced NF- $\kappa$ B transcriptional activity (Fig. 4a). In spite of this potent NF- $\kappa$ B inhibitory capacity, the palmitate-induced reduction of glucose uptake could not be prevented by parthenolide (Fig. 4b), which-in line with the amidepsine findings - suggests that palmitate-induced NF- $\kappa \mathrm{B}$ activation and insulin resistance are not causally related.

To further confirm these findings, we also inhibited the NF- $\kappa \mathrm{B}$ pathway by genetic modification, using $\mathrm{I} \kappa \mathrm{B} \alpha-\mathrm{SR}$, a non-degradable mutant of $\mathrm{I} \kappa \mathrm{B} \alpha$. As expected, increased NF- $\kappa \mathrm{B}$ DNA binding after treatment with palmitate (Fig. 5a) or TNF $\alpha$ (data not shown) was not observed in L6 cells expressing the $\mathrm{I} \kappa \mathrm{B} \alpha$-super repressor (SR), in contrast to control myotubes. In complete accordance with the parthenolide results, there was no improvement in insulininduced glucose uptake in $\mathrm{I} \kappa \mathrm{B} \alpha-\mathrm{SR}$ myotubes treated with palmitate (Fig. 5b). Thus, neither pharmacological and genetic blockade of NF- $\kappa \mathrm{B}$ could prevent palmitateinduced insulin resistance in skeletal muscle cells, illustrating NF- $\kappa \mathrm{B}$ activity in skeletal muscle is not required for palmitate-induced insulin resistance.

\section{Discussion}

Lipid infusion-induced insulin resistance in human skeletal muscle is asscociated with an increase in diacylglycerol (DAG) mass and a reduction in $\mathrm{I} \kappa \mathrm{B} \alpha$ protein levels [8]. This led to the suggestion that DAG accumulation, NF- $\kappa \mathrm{B}$ activation and insulin resistance are causally related. Here, we show that palmitate-induced insulin resistance in 

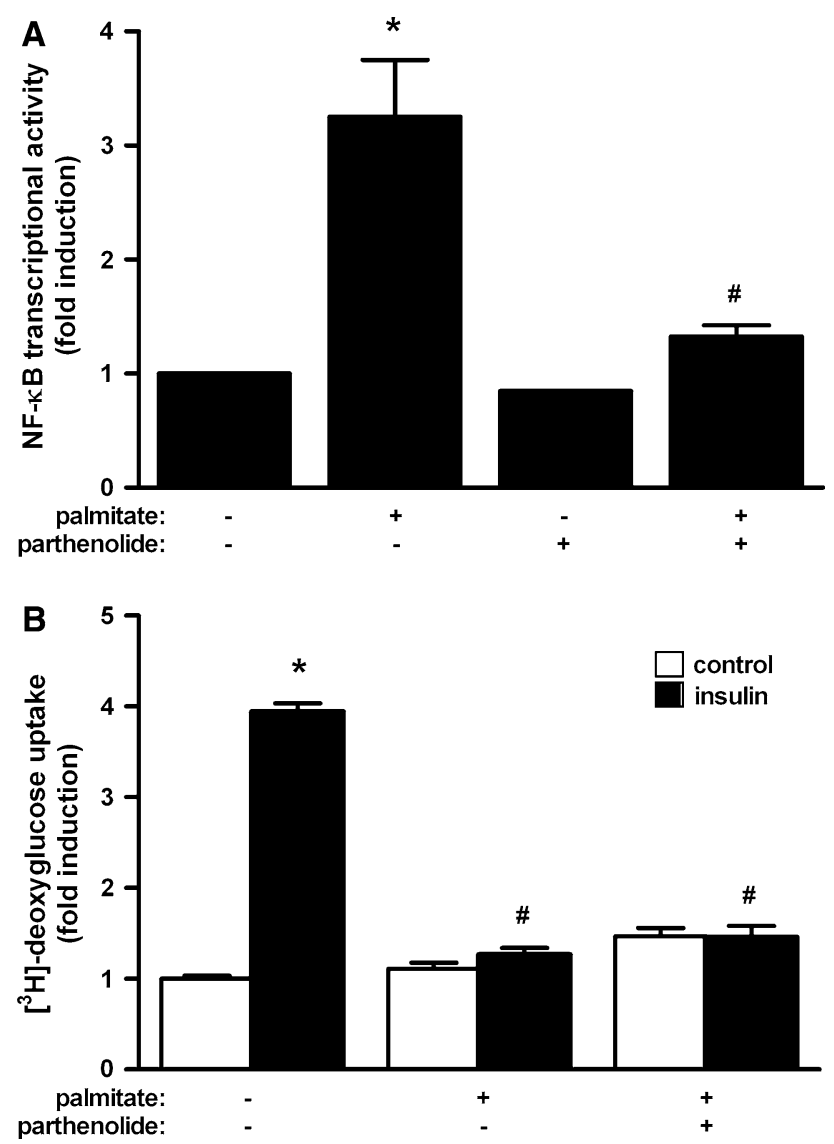

Fig. 4 Pharmacological inhibition of NF- $\kappa \mathrm{B}$ does not prevent palmitate-induced insulin resistance in myotubes a $\mathrm{C} 2 \mathrm{C} 12$ myoblasts stably transfected with the $6 \kappa \mathrm{B}$-TK-luciferase construct were differentiated for 5 days and incubated with $400 \mu \mathrm{mol} / \mathrm{l}$ palmitate and 20 $\mu \mathrm{mol} / 1$ parthenolide for $24 \mathrm{~h}$ as indicated. Lysates were prepared for assessment of luciferase activity. Values were corrected for protein content and expressed as fold-induction over control. ${ }^{*} P<0.05$ versus control. ${ }^{\#} P<0.05$ versus non-parthenolide palmitate-treated cells. b L6 myotubes were treated for $16 \mathrm{~h}$ with $200 \mu \mathrm{mol} / \mathrm{l}$ palmitate in presence or absence of $20 \mu \mathrm{mol} / 1$ parthenolide prior to insulin stimulation (open bars no insulin stimulation; black bars insulin stimulation). 2-deoxyglucose uptake was measured as described in "Materials and methods", and insulin-stimulated glucose uptake was expressed as fold induction over basal (non-insulin stimulated) glucose uptake. ${ }^{*} P<0.05$ versus control. ${ }^{\#} P<0.05$ versus insulinstimulated control

skeletal muscle cells indeed coincides with increased NF$\kappa \mathrm{B}$ activation and DAG accumulation.

However, our intramyocellular lipid metabolite modulating experiments uncoupled the effects of palmitate-induced DAG accumulation and insulin resistance from NF- $\kappa$ B activation. Furthermore, pharmacological and genetic inhibition of the $\mathrm{NF}-\kappa \mathrm{B}$ pathway could not prevent the palmitate-induced reduction in insulin-stimulated glucose uptake. Altogether, this implies that NF- $\kappa \mathrm{B}$ activation is not a causal factor in palmitate-induced insulin resistance in skeletal muscle.

FA oversupply results in increased intra-myocellular lipid (IMCL) and consequent lipid metabolite accumulation, and
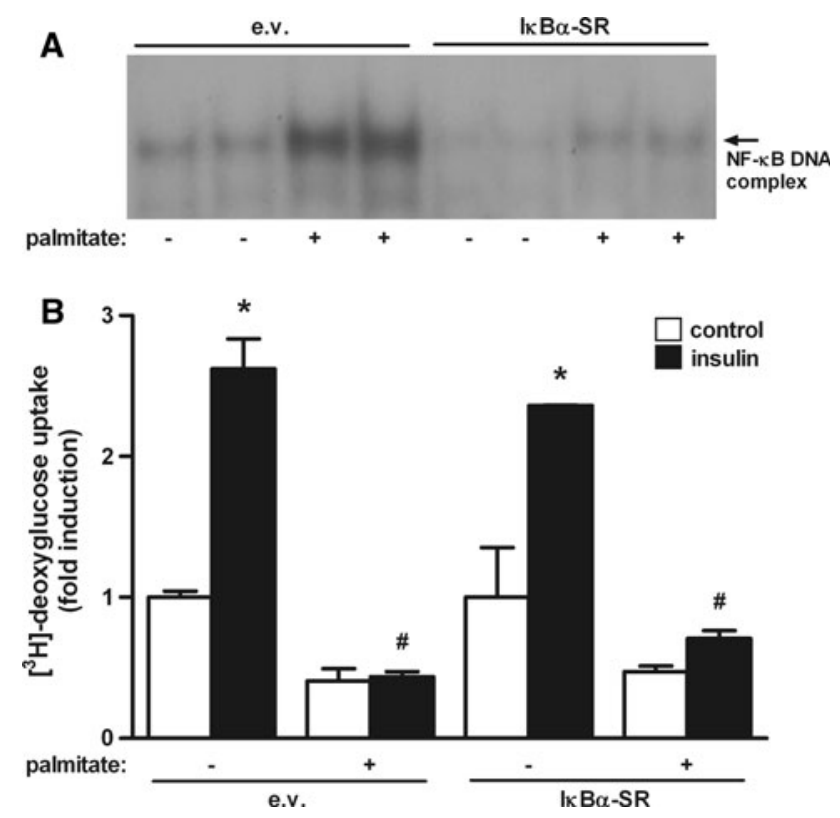

Fig. 5 Genetic inhibition of NF- $\kappa \mathrm{B}$ does not prevent palmitateinduced insulin resistance in myotubes Stably transfected L6 cells, carrying a plasmid encoding a stabilized mutant of the Inhibitor of $\mathrm{NF}-\kappa \mathrm{B}(\mathrm{I} \kappa \mathrm{B} \alpha-\mathrm{SR})$ or an empty vector (e.v.), were differentiated for 5 days and cultured for $16 \mathrm{~h}$ in presence or absence of $200 \mu \mathrm{mol} / 1$ palmitate. a Nuclear extracts were prepared and assessed for DNA binding activity to a consensus NF- $\kappa \mathrm{B}$ oligonucleotide by EMSA. b Control- or $\mathrm{I} \kappa \mathrm{B} \alpha$-SR-myotubes were treated for $16 \mathrm{~h}$ with 200 $\mu \mathrm{mol} / 1$ palmitate prior to insulin stimulation (open bars no insulin stimulation; black bars insulin stimulation). 2-deoxyglucose uptake was measured as described in "Materials and methods", and insulinstimulated glucose uptake was expressed as fold induction over own basal (non-insulin stimulated) glucose uptake. ${ }^{*} P<0.05$ versus control

this was reproduced by pharmacological inhibition of carnitine palmitoyltransferase 1 (CPT-1) using etomoxir. By irreversible inhibition of CPT-1, etomoxir is able to block the entry of long-chain fatty acyl-CoA into mitochondria [30,33, 34]. Consequently, CPT-1 inhibition results in intramyocellular lipid (IMCL) accumulation [29] and may therefore lead to cytoplasmatic accumulation of lipid metabolites, like palmitoyl-CoA, DAG and ceramide, which have all been implicated in the pathogenesis of insulin resistance in skeletal muscle [8, 11, 35-39]. Indeed, treatment with etomoxir sensitized myotubes to palmitate-induced DAG accumulation and insulin resistance, causing decreased insulin-stimulated glucose uptake even with non-insulin resistance-inducing palmitate concentrations. These results are in agreement with a study in rats, where inhibition of CPT-1 by prolonged etomoxir administration resulted in increased IMCL accumulation, associated with insulin resistance [29]. Furthermore, CPT-1 over-expression in L6E9 muscle cells prevented DAG and ceramide accumulation and activation of protein kinase $\mathrm{C}$ (PKC) $-\theta$ and $-\zeta$ after palmitate incubation, and resulted in protection from palmitate-induced insulin resistance [40]. 
Another approach to manipulate accumulation of lipid metabolites is by inhibiting diacylglycerol acyltransferase (DGAT), the enzyme facilitating binding of DAG to longchain acyl-CoAs to form triacylglycerol (TAG), using amidepsine A [31, 41]. In accordance with the etomoxir results, we found that inhibiting DGAT by amidepsine A resulted in DAG accumulation and sensitized myotubes to palmitateinduced insulin resistance. In line with this, over-expression of DGAT1 in skeletal muscle of mice resulted in protection against high fat diet-induced insulin resistance, which coincided with decreased DAG and ceramide levels and increased TAG levels [42]. This was associated with attenuated fatinduced activation of JNK and DAG-responsive PKCs. Furthermore, the same authors showed that, in isolated soleus muscle from DGAT knockout mice, the insulin-induced reduction in glucose uptake after administration of a palmitate/oleate mixture is exacerbated compared to wild-type muscle, which coincided with increased DAG and ceramide levels. Conversely, muscles over-expressing DGAT1 showed enhanced insulin sensitivity, associated with decreased DAG and ceramide levels (comparable to muscle from wild-type mice) [42]. Whether DAG or ceramides are responsible for palmitate-induced insulin resistance cannot be concluded from our experiments, since accumulation of palmitoyl-CoA might not only lead to the formation of DAG, but also to ceramides. Since palmitoyl-CoA is a precursor in sphingolipid synthesis [43], etomoxir or amidepsine treatment may lead to enhanced ceramide synthesis, as has been reported for etomoxir in hematopoietic cell lines [44].

While etomoxir alone did not induce NF- $\kappa$ B activation, it did increase NF- $\kappa$ B transactivation when co-incubated with $100 \mu \mathrm{mol} / \mathrm{l}$ palmitate. However, in contrast to etomoxir, direct interference with DAG metabolism by inhibiting the conversion from DAG to TAG with amidepsine did not increase palmitate-induced NF- $\kappa$ B transactivation. Based on these results, it is unlikely that DAG or DAG-induced PKC activation is responsible for NF- $\kappa \mathrm{B}$ activation as DAG accumulation was observed in response to both etomoxir and amidepsine. Ceramides are known activators of NF- $\kappa \mathrm{B}$ $[45,46]$ and are therefore a likely candidate for the observed NF- $\kappa \mathrm{B}$ activation in response to palmitate.

Moreover, these differential effects of lipid metabolite modulation on insulin resistance and NF- $\kappa \mathrm{B}$ activation suggest that FA-induced insulin resistance and NF- $\kappa \mathrm{B}$ activation in skeletal muscle are not related. This dissociation between FA-induced NF- $\kappa \mathrm{B}$ activity and insulin resistance was also postulated in a recent study from our group [23], in which we showed that several unsaturated fatty acids were able to increase NF- $\kappa$ B DNA binding and transcriptional activity in myotubes without inducing insulin resistance, which further supports that fatty acidinduced insulin resistance and NF- $\kappa \mathrm{B}$ activation in muscle may occur independently.
Several studies in rodents and humans show that fatinduced insulin resistance is associated with NF- $\kappa \mathrm{B}$ activation in skeletal muscle $[8,15,16]$. Although previous associations between palmitate-induced insulin resistance and NF- $\kappa \mathrm{B}$ activation in skeletal muscle cells have also been reported $[12,14]$, we now show by pharmacological and by genetic inhibition that a causal relationship between both processes can be ruled out.

Previous studies investigating this potential association used inhibition of IKK by high doses of salicylate or by heterozygous deletion, which prevented lipid infusion-, obesity- and diet-induced insulin resistance in skeletal muscle [17, 18]. However, it has been shown that salicylate may reverse TNF- $\alpha$-induced insulin resistance independently of IKK-2/NF- $\kappa$ B inhibition [47]. In this study, salicylate inhibited JNK activation, and the latter has also implicated in obesity-induced insulin resistance [48]. Furthermore, there is evidence from several in vivo studies that the NF- $\kappa \mathrm{B}$ pathway in skeletal muscle is not required for high-fat diet-induced insulin resistance. Muscle-specific inhibition of NF- $\kappa \mathrm{B}$ by transgenic expression of the $\mathrm{I} \kappa \mathrm{B} \alpha$ super-repressor (MISR mice) did not protect against the development of obesity-induced insulin resistance, following a high fat diet for 3 months [19]. Muscle-specific IKK-2-deficient mice were not protected against whole body or muscle insulin resistance induced by gold thioglucose or high-fat [20]. Taken together, these in vivo studies suggest that activation of the NF- $\kappa \mathrm{B}$ pathway in muscle does not seem to play a causal role in high-fatinduced insulin resistance.

In fact, the evidence causally relating FA-induced insulin resistance in muscle to NF- $\kappa \mathrm{B}$ activation is entirely derived from in vitro studies using L6 skeletal muscle cells [21], in which it was shown that pharmacological inhibition of IKK (using parthenolide and acetylsalicylate) or blockade of nuclear translocation of NF- $\kappa$ B prevented palmitateinduced reductions in insulin-stimulated glucose uptake. The acetylsalicylate-induced effects on insulin resistance may be IKK independent, since it is known that acetylsalicylate blocks several kinases, including JNK, [49], which as pointed out above has been implicated in insulin resistance. In addition, SN50, a peptide used to block nuclear import of NF- $\kappa \mathrm{B}$ [50], was used as proof that nuclear translocation of NF- $\kappa \mathrm{B}$ is required for the insulin-desensitizing effects of palmitate [21]. However, these data should be interpreted with care as SN50 displays inhibitory activity towards the nuclear translocation of a range of transcription factors other than $\mathrm{NF}-\kappa \mathrm{B}$ [51]. Importantly, SN50 also blocks nuclear import of activator protein (AP)1 , which is a JNK-responsive transcription factor, suggesting that reversal of insulin resistance by SN50 can also be explained by inhibition of the JNK/AP-1 pathway which has been implicated in insulin resistance [48]. 
In contrast to the observations concerning reversal of insulin sensitivity following NF- $\kappa \mathrm{B}$ inhibition by parthenolide [21], in our hands parthenolide, despite complete ablation of $\mathrm{NF}-\kappa \mathrm{B}$ activation, displayed no protection against palmitate-induced insulin resistance. Although it is difficult to reconcile these opposing findings, we are confident of our data as a second, genetic approach to inhibit NF- $\kappa \mathrm{B}$ yielded identical results. Here, we showed that complete ablation of NF- $\kappa \mathrm{B}$ activation by $\mathrm{I} \kappa \mathrm{B} \alpha-\mathrm{SR}$ in L6 cells did not prevent palmitate-induced insulin resistance. A similar strategy to inhibit muscular NF- $\kappa \mathrm{B}$ activation also ruled out a role of muscle NF- $\kappa \mathrm{B}$ in highfat-induced insulin resistance [19]. Although insulin resistance of other tissues could potentially have masked a protective effect of $\mathrm{NF}-\kappa \mathrm{B}$ inhibition in muscle as whole body insulin sensitivity was measured in that study, our findings further extend the evidence against an important role for $\mathrm{NF}-\kappa \mathrm{B}$ in skeletal muscle insulin resistance as insulin sensitivity was measured directly in cultured muscle. Finally, in line with previous reports [24-26], LPS and TNF- $\alpha$ were not able to induce insulin resistance in myotubes despite potent NF- $\kappa \mathrm{B}$ activation (data not shown). This further confirms findings that muscle-specific NF- $\kappa \mathrm{B}$ activation is not sufficient to induce insulin resistance $[19,52]$, and underlines the notion that $\mathrm{NF}-\kappa \mathrm{B}$ activation and insulin resistance in skeletal muscle are not causally related.

In conclusion, we demonstrate that manipulation of DAG accumulation by inhibiting DGAT or $\beta$-oxidation resulted in segregation of palmitate-induced insulin resistance and NF- $\kappa \mathrm{B}$ activation, suggesting that these processes are not related. By pharmacological and genetic inhibition of the NF- $\kappa \mathrm{B}$ pathway, we reveal that activation of the NF- $\kappa \mathrm{B}$ pathway is not required for palmitateinduced insulin resistance in skeletal muscle cells.

Open Access This article is distributed under the terms of the Creative Commons Attribution Noncommercial License which permits any noncommercial use, distribution, and reproduction in any medium, provided the original author(s) and source are credited.

\section{References}

1. Zimmet P, Alberti KG, Shaw J (2001) Global and societal implications of the diabetes epidemic. Nature 414:782-787

2. Parker DR, Weiss ST, Troisi R, Cassano PA, Vokonas PS, Landsberg L (1993) Relationship of dietary saturated fatty acids and body habitus to serum insulin concentrations: the normative aging study. Am J Clin Nutr 58:129-136

3. DeFronzo RA, Jacot E, Jequier E, Maeder E, Wahren J, Felber JP (1981) The effect of insulin on the disposal of intravenous glucose. Results from indirect calorimetry and hepatic and femoral venous catheterization. Diabetes 30:1000-1007
4. Reaven GM, Hollenbeck C, Jeng CY, Wu MS, Chen YD (1988) Measurement of plasma glucose, free fatty acid, lactate, and insulin for $24 \mathrm{~h}$ in patients with NIDDM. Diabetes 37:1020-1024

5. Qvigstad E, Mostad IL, Bjerve KS, Grill VE (2003) Acute lowering of circulating fatty acids improves insulin secretion in a subset of type 2 diabetes subjects. Am J Physiol Endocrinol Metab 284:E129-E137

6. Ahren B (2001) Reducing plasma free fatty acids by acipimox improves glucose tolerance in high-fat fed mice. Acta Physiol Scand 171:161-167

7. Yu C, Chen Y, Cline GW, Zhang D, Zong H, Wang Y, Bergeron R, Kim JK, Cushman SW, Cooney GJ, Atcheson B, White MF, Kraegen EW, Shulman GI (2002) Mechanism by which fatty acids inhibit insulin activation of insulin receptor substrate-1 (IRS-1)-associated phosphatidylinositol 3-kinase activity in muscle. J Biol Chem 277:50230-50236

8. Itani SI, Ruderman NB, Schmieder F, Boden G (2002) Lipidinduced insulin resistance in human muscle is associated with changes in diacylglycerol, protein kinase $\mathrm{C}$, and IkappaB-alpha. Diabetes 51:2005-2011

9. Griffin ME, Marcucci MJ, Cline GW, Bell K, Barucci N, Lee D, Goodyear LJ, Kraegen EW, White MF, Shulman GI (1999) Free fatty acid-induced insulin resistance is associated with activation of protein kinase $\mathrm{C}$ theta and alterations in the insulin signaling cascade. Diabetes 48:1270-1274

10. Lee JS, Pinnamaneni SK, Eo SJ, Cho IH, Pyo JH, Kim CK, Sinclair AJ, Febbraio MA, Watt MJ (2006) Saturated, but not n-6 polyunsaturated, fatty acids induce insulin resistance: role of intramuscular accumulation of lipid metabolites. J Appl Physiol 100:1467-1474

11. Chavez JA, Summers SA (2003) Characterizing the effects of saturated fatty acids on insulin signaling and ceramide and diacylglycerol accumulation in 3T3-L1 adipocytes and $\mathrm{C} 2 \mathrm{C} 12$ myotubes. Arch Biochem Biophys 419:101-109

12. Hommelberg PP, Plat J, Langen RC, Schols AM, Mensink RP (2009) Fatty acid-induced NF-\{kappa $\}$ B activation and insulin resistance in skeletal muscle are chain length dependent. Am J Physiol Endocrinol Metab 296:E114-E120

13. Weigert C, Brodbeck K, Staiger H, Kausch C, Machicao F, Haring HU, Schleicher ED (2004) Palmitate, but not unsaturated fatty acids, induces the expression of interleukin- 6 in human myotubes through proteasome-dependent activation of nuclear factor-kappaB. J Biol Chem 279:23942-23952

14. Jove M, Planavila A, Sanchez RM, Merlos M, Laguna JC, Vazquez-Carrera M (2006) Palmitate induces tumor necrosis factoralpha expression in $\mathrm{C} 2 \mathrm{C} 12$ skeletal muscle cells by a mechanism involving protein kinase $\mathrm{C}$ and nuclear factor-kappaB activation. Endocrinology 147:552-561

15. Bhatt BA, Dube JJ, Dedousis N, Reider JA, O'Doherty RM (2006) Diet-induced obesity and acute hyperlipidemia reduce IkappaBalpha levels in rat skeletal muscle in a fiber-type dependent manner. Am J Physiol Regul Integr Comp Physiol 290:R233-R240

16. Ropelle ER, Pauli JR, Prada PO, de Souza CT, Picardi PK, Faria MC, Cintra DE, Fernandes MF, Flores MB, Velloso LA, Saad MJ, Carvalheira JB (2006) Reversal of diet-induced insulin resistance with a single bout of exercise in the rat: the role of PTP1B and IRS-1 serine phosphorylation. J Physiol 577:997-1007

17. Yuan M, Konstantopoulos N, Lee J, Hansen L, Li ZW, Karin M, Shoelson SE (2001) Reversal of obesity- and diet-induced insulin resistance with salicylates or targeted disruption of Ikkbeta. Science 293:1673-1677

18. Kim JK, Kim YJ, Fillmore JJ, Chen Y, Moore I, Lee J, Yuan M, Li ZW, Karin M, Perret P, Shoelson SE, Shulman GI (2001) Prevention of fat-induced insulin resistance by salicylate. J Clin Invest 108:437-446 
19. Cai D, Frantz JD, Tawa NE Jr, Melendez PA, Oh BC, Lidov HG, Hasselgren PO, Frontera WR, Lee J, Glass DJ, Shoelson SE (2004) IKKbeta/NF-kappaB activation causes severe muscle wasting in mice. Cell 119:285-298

20. Rohl M, Pasparakis M, Baudler S, Baumgartl J, Gautam D, Huth M, De Lorenzi R, Krone W, Rajewsky K, Bruning JC (2004) Conditional disruption of IkappaB kinase 2 fails to prevent obesity-induced insulin resistance. J Clin Invest 113:474-481

21. Sinha S, Perdomo G, Brown NF, O'Doherty RM (2004) Fatty acid-induced insulin resistance in 16 myotubes is prevented by inhibition of activation and nuclear localization of nuclear factor kB. J Biol Chem 279:41294-41301

22. Radin MS, Sinha S, Bhatt BA, Dedousis N, O'Doherty RM (2008) Inhibition or deletion of the lipopolysaccharide receptor Toll-like receptor-4 confers partial protection against lipidinduced insulin resistance in rodent skeletal muscle. Diabetologia $51: 336-346$

23. Hommelberg PP, Langen RC, Schols AM, van Essen AL, Snepvangers FJ, Mensink RP, Plat J (2010) Trans fatty acidinduced NF-kappaB activation does not induce insulin resistance in cultured murine skeletal muscle cells. Lipids 45:285-290

24. Roher N, Samokhvalov V, Diaz M, MacKenzie S, Klip A, Planas JV (2008) The proinflammatory cytokine tumor necrosis factoralpha increases the amount of glucose transporter- 4 at the surface of muscle cells independently of changes in interleukin-6. Endocrinology 149:1880-1889

25. Lee MD, Zentella A, Vine W, Pekala PH, Cerami A (1987) Effect of endotoxin-induced monokines on glucose metabolism in the muscle cell line L6. Proc Natl Acad Sci USA 84:2590-2594

26. Yamasaki H, Yamaguchi Y, Takino H, Matsuo H, Matsumoto K, Uotani S, Akazawa S, Yamashita S, Nagataki S (1996) TNFalpha stimulates glucose uptake in L6 myoblasts. Diab Res Clin Pract 32:11-18

27. Polkinghorne E, Lau Q, Cooney GJ, Kraegen EW, Cleasby ME (2008) Local activation of the I\{kappa\}K-NF\{kappa\}B pathway in muscle does not cause insulin resistance. Am J Physiol Endocrinol Metab 294:E316-E325

28. Langen RC, Schols AM, Kelders MC, Wouters EF, JanssenHeininger YM (2003) Enhanced myogenic differentiation by extracellular matrix is regulated at the early stages of myogenesis. In Vitro Cell Dev Biol Anim 39:163-169

29. Dobbins RL, Szczepaniak LS, Bentley B, Esser V, Myhill J, McGarry JD (2001) Prolonged inhibition of muscle carnitine palmitoyltransferase-1 promotes intramyocellular lipid accumulation and insulin resistance in rats. Diabetes 50:123-130

30. Lilly K, Chung C, Kerner J, VanRenterghem R, Bieber LL (1992) Effect of etomoxiryl-CoA on different carnitine acyltransferases. Biochem Pharmacol 43:353-361

31. Tomoda H, Ito M, Tabata N, Masuma R, Yamaguchi Y, Omura S (1995) Amidepsines, inhibitors of diacylglycerol acyltransferase produced by Humicola sp. FO-2942. I. Production, isolation and biological properties. J Antibiot (Tokyo) 48:937-941

32. Kwok BH, Koh B, Ndubuisi MI, Elofsson M, Crews CM (2001) The anti-inflammatory natural product parthenolide from the medicinal herb Feverfew directly binds to and inhibits IkappaB kinase. Chem Biol 8:759-766

33. Declercq PE, Falck JR, Kuwajima M, Tyminski H, Foster DW, McGarry JD (1987) Characterization of the mitochondrial carnitine palmitoyltransferase enzyme system I. Use of inhibitors. J Biol Chem 262:9812-9821

34. Agius L, Meredith EJ, Sherratt HS (1991) Stereospecificity of the inhibition by etomoxir of fatty acid and cholesterol synthesis in isolated rat hepatocytes. Biochem Pharmacol 42:1717-1720

35. Schmitz-Peiffer C, Browne CL, Oakes ND, Watkinson A, Chisholm DJ, Kraegen EW, Biden TJ (1997) Alterations in the expression and cellular localization of protein kinase $\mathrm{C}$ isozymes epsilon and theta are associated with insulin resistance in skeletal muscle of the high-fat-fed rat. Diabetes 46:169-178

36. Schmitz-Peiffer C, Craig DL, Biden TJ (1999) Ceramide generation is sufficient to account for the inhibition of the insulin-stimulated $\mathrm{PKB}$ pathway in $\mathrm{C} 2 \mathrm{C} 12$ skeletal muscle cells pretreated with palmitate. J Biol Chem 274:24202-24210

37. Adams JM 2nd, Pratipanawatr T, Berria R, Wang E, DeFronzo RA, Sullards MC, Mandarino LJ (2004) Ceramide content is increased in skeletal muscle from obese insulin-resistant humans. Diabetes 53:25-31

38. Straczkowski M, Kowalska I, Nikolajuk A, Dzienis-Straczkowska S, Kinalska I, Baranowski M, Zendzian-Piotrowska M, Brzezinska Z, Gorski J (2004) Relationship between insulin sensitivity and sphingomyelin signaling pathway in human skeletal muscle. Diabetes 53:1215-1221

39. Oakes ND, Bell KS, Furler SM, Camilleri S, Saha AK, Ruderman NB, Chisholm DJ, Kraegen EW (1997) Diet-induced muscle insulin resistance in rats is ameliorated by acute dietary lipid withdrawal or a single bout of exercise: parallel relationship between insulin stimulation of glucose uptake and suppression of long-chain fatty acyl-CoA. Diabetes 46:2022-2028

40. Sebastian D, Herrero L, Serra D, Asins G, Hegardt FG (2007) CPT I overexpression protects L6E9 muscle cells from fatty acidinduced insulin resistance. Am J Physiol Endocrinol Metab 292:E677-E686

41. Cases S, Smith SJ, Zheng YW, Myers HM, Lear SR, Sande E, Novak S, Collins C, Welch CB, Lusis AJ, Erickson SK, Farese RV Jr (1998) Identification of a gene encoding an acyl CoA:diacylglycerol acyltransferase, a key enzyme in triacylglycerol synthesis. Proc Natl Acad Sci USA 95:13018-13023

42. Liu L, Zhang Y, Chen N, Shi X, Tsang B, Yu YH (2007) Upregulation of myocellular DGAT1 augments triglyceride synthesis in skeletal muscle and protects against fat-induced insulin resistance. J Clin Invest 117:1679-1689

43. Merrill AH Jr, Jones DD (1990) An update of the enzymology and regulation of sphingomyelin metabolism. Biochim Biophys Acta 1044:1-12

44. Paumen MB, Ishida Y, Muramatsu M, Yamamoto M, Honjo T (1997) Inhibition of carnitine palmitoyltransferase I augments sphingolipid synthesis and palmitate-induced apoptosis. J Biol Chem 272:3324-3329

45. Kouba DJ, Nakano H, Nishiyama T, Kang J, Uitto J, Mauviel A (2001) Tumor necrosis factor-alpha induces distinctive NF-kappa B signaling within human dermal fibroblasts. J Biol Chem 276:6214-6224

46. Demarchi F, Bertoli C, Greer PA, Schneider C (2005) Ceramide triggers an NF-kappaB-dependent survival pathway through calpain. Cell Death Differ 12:512-522

47. Jiang G, Dallas-Yang Q, Liu F, Moller DE, Zhang BB (2003) Salicylic acid reverses phorbol 12-myristate-13-acetate (PMA)and tumor necrosis factor alpha (TNFalpha)-induced insulin receptor substrate 1 (IRS1) serine 307 phosphorylation and insulin resistance in human embryonic kidney 293 (HEK293) cells. J Biol Chem 278:180-186

48. Hirosumi J, Tuncman G, Chang L, Gorgun CZ, Uysal KT, Maeda K, Karin M, Hotamisligil GS (2002) A central role for JNK in obesity and insulin resistance. Nature 420:333-336

49. Gao Z, Zuberi A, Quon MJ, Dong Z, Ye J (2003) Aspirin inhibits serine phosphorylation of insulin receptor substrate 1 in tumor necrosis factor-treated cells through targeting multiple serine kinases. J Biol Chem 278:24944-24950

50. Lin YZ, Yao SY, Veach RA, Torgerson TR, Hawiger J (1995) Inhibition of nuclear translocation of transcription factor NFkappa $\mathrm{B}$ by a synthetic peptide containing a cell membranepermeable motif and nuclear localization sequence. J Biol Chem 270:14255-14258 
51. Torgerson TR, Colosia AD, Donahue JP, Lin YZ, Hawiger J (1998) Regulation of NF-kappa B, AP-1, NFAT, and STAT1 nuclear import in $\mathrm{T}$ lymphocytes by noninvasive delivery of peptide carrying the nuclear localization sequence of NF-kappa B p50. J Immunol 161:6084-6092
52. Polkinghorne E, Lau Q, Cooney GJ, Kraegen EW, Cleasby ME (2008) Local activation of the IkappaK-NF-kappaB pathway in muscle does not cause insulin resistance. Am J Physiol Endocrinol Metab 294:E316-E325 